\title{
The Effectiveness of Melt-Blown Filter Cartridge and UV-C Rays on the Reduction of Total Coliform and Water Hardness in Production Process Water
}

\author{
Elanda Fikri' ${ }^{1,2}$, Nursyifa Yuliani Putri', Nanny Djuhriah', \\ Neneng Yetty Hanurawaty ${ }^{1}$, Amar Sharaf Eldin Khair ${ }^{3}$ \\ 1 Department of Environmental Health, Bandung Health Polytechnic, North Cimahi, 40514, Indonesia \\ 2 Center of Excellence, Bandung Health Polytechnic, Jalan Pajajaran 56, Bandung, 40171, Indonesia \\ 3 Geography Department, Omdurman Islamic University, Omdurman City, Sudan \\ * Corresponding author's email: elandafikri@yahoo.com
}

\begin{abstract}
Water is one of the humans' basic needs that are essential in daily lives. The water use related to the production of the food processing industry must at least meet the quality standards required for drinking water. The Production process water is obtained from the artesian well that has been treated with a physical treatment process. The microbiological examination result of total Coliform is $8.6 \mathrm{MPN} / 100 \mathrm{ml}$ meaning that it does not meet the quality standard requirements, which is 0 MPN/100 ml (The Minister of Health Regulation Number 492 of 2010, concerning Drinking Water Quality Requirements), it is necessary to treat the production process water using a Melt Blown Filter (MBF) and UV-C rays. The purpose of this study was to determine the differences in the variation of the 1, 3, and 5-micron of Melt Blown Filter cartridge 10" in reducing the amount of total Coliform, as well as the water hardness and their effect on disinfection using UV-C rays. The type of research used is experimental research with a pretest-posttest without control research design. There is a reduction in the average total Coliform after the treatment using a Melt Blown Filter, with a result of 1, 3, and 5-micron as 2.95 MPN /100ml, $3.61 \mathrm{MPB} / 100 \mathrm{ml}$, and $7.31 \mathrm{MPN} / 100 \mathrm{ml}$ with a percentage reduction of $100 \%, 94.5 \%$, and $82.4 \%$, respectively. The average total Coliform using the Melt Blown Filter equipped with the UV-C rays treatment resulted in a reduction of 1, 3, and 5-micron as 2.95 MPN/100 ml, 3.95 MPN/100 ml, $8.88 \mathrm{MPN} / 100 \mathrm{ml}$ respectively, with a reduction percentage of $100 \%$, for each treatment. The data analysis for total coliform using the One-Way ANOVA test resulted in a pvalue of 0.001 , the effective variation obtained is 1-micron MBF equipped with UV-C rays. The analysis of results pertaining to the water hardness data showed that the use of Melt Blown Filter could not reduce water hardness, but the UV-C rays could still be used accordingly. The data analysis for water hardness was performed using KruskalWallis with a p-value of 0.820 , meaning that there are no differences in Melt Blown Filter variation on the results of total water hardness value.
\end{abstract}

Keywords: melt blown filter cartridge, ultraviolet-c, total coliform, water hardness.

\section{INTRODUCTION}

Water is one of the humans' basic needs that are essential in daily lives, be it for consumption such as drinking, or other activities such as bathing, washing, latrines, and so on. Water for consumption including the use of water for cooking must meet the physical, chemical, and microbiological requirements in order to prevent the cause of diseases in humans according to The Minister of Health Regulation Number 492 of 2010, concerning Drinking Water Quality Requirements. The $\mathrm{X}$ Industry is a company engaged in the manufacturing of bread. The use of water that is related to the manufacturing (food processing) process must at least meet the drinking water quality standards. The sanitation principles must be applied in the Standard Sanitation Operating 
Procedure (SSOP) in the food industry to prevent food contamination. The water used for the drinking and manufacturing process in the industry is obtained from the artesian well, which is treated first by resin water filters and activated carbon media, subsequently distributed through distribution pipes in the industry. On the basis of the examination result from the Health Center of West Java Province on 26 April 2021, the total Coliform number is $8.6 \mathrm{MPN} / 100 \mathrm{ml}$, which does not meet the standard of the water production process, although the coliform number does not meet the requirements, the water hardness has met the requirements with a result of $60.48 \mathrm{mg} / \mathrm{L}$.

The filtration process using a 3 and 1-micrometer Melt Blown Filter Cartridge resulted in a decrease in total Coliform, this is because the size of the filter media used was 3 and $1 \mathrm{mi}-$ crometer (Mulyatna, 2019) It is known that the Coliform bacteria have a size of $0.5-3$ micrometers. The Melt Blown filter cartridge allows Coliform to adhere to the filter fibers. This filter cartridge is made of Polypropylene (Kanade, 2013), its porous surface is ideal to detain inorganic particles and bacteria which further form a biofilm (Prayitno, 2019). The $254 \mathrm{~nm}$ wavelength of Ultraviolet-C rays with a power of 30 watts is known to be an effective germicide, a contact time of 50 seconds or less than 1 minute of UV-C rays is known to be effective in eliminating microorganisms (Yuliana, 2020). One of the disadvantages of disinfecting using Ultraviolet- $\mathrm{C}$ rays is the formation of a biofilm on the surface of the lamp; hence, the pretreatment of filtration is required in order to reach effectiveness in disinfecting, because the sediments and other contaminants from shadows prevent the UV rays from reaching microorganisms (Wulansarie, 2012), this is caused by one of the inhibitor contaminants called water hardness.

The higher the water hardness level, the smaller the microbial death constant is, which will cause the disinfection process using UV rays to be more ineffective, because the microbial death rate is lower. This is due to the content of calcium and magnesium contained in the water with moderate and high-water hardness levels, that could settle on the surface of the lamp socket. When UV rays pass through these sediments, photons will be scattered or discarded so that the UV intensity decreases (Maley, 2004 $\&$ EPA 2003). On the basis of the explanation above, the research will be conducted on the effectiveness of Melt Blown Filter Cartridge and UV-C rays on the total reduction of Coliform and Water Hardness level of water used for the production process in Industry X.

\section{METHODS}

The type of conducted research is experimental research with a pre-test-post-test without control design. The purpose of this study was to reduce the total Coliform and total water hardness and to determine the effectiveness of the Melt Blown filter cartridge and UV-C rays with variations of the Melt Blown filter cartridge 10" 1,3 , and 5 microns. The research was conducted in May-June 2021 at X Industry. The sample of water for the experiment is obtained from the reservoir chiller of Building B at X Industry. There are 6 samples required for each treatment, each sample is divided into two samples (pretest and posttest); hence, there are two samples of pretest and posttest for the first, second, and third treatment which is 1,3 , and 5 microns, respectively, with 6 repetitions for each treatment in the experiment. The tool in this experiment consisted of three 10 " housing filters with various sizes of 1,3 , and 5 microns of Melt Blown Filters equipped with Ultraviolet-C (Figure 1-3). The water for the production process will be in contact with the Melt Blown Filter Cartridge for the first filtration treatment in order for bacteria to be filtered when passing through the Melt Blown Filter Cartridge, if there are still bacteria found after the filtration process, it will be streamed into the Ultraviolet-C Rays to reduce the Coliform bacteria. The method of coliform examination is based on the Indonesian National Standard (SNI) 01-2897-1992 and SNI. 06-6989. 13-2004 for water hardness examination.

On the basis of te results of the One-Way ANOVA test, the $p$-value is at $0.001<0.05$, thus $\mathrm{Ha}$ is accepted, meaning there are differences in the variation of Melt Blown Filter and UV-C rays on the total amount of Coliform in the production process water at $\mathrm{X}$ Industry. As for the results of the Kruskal-Wallis test, the p-value is at $0.820>$ 0.05 , thus Ho is accepted, meaning there are no significant differences in the variation of 1,3 , and 5 microns of Melt Blown Filter and UV-C rays on the total water hardness results of production process water at Industry $\mathrm{X}$. 


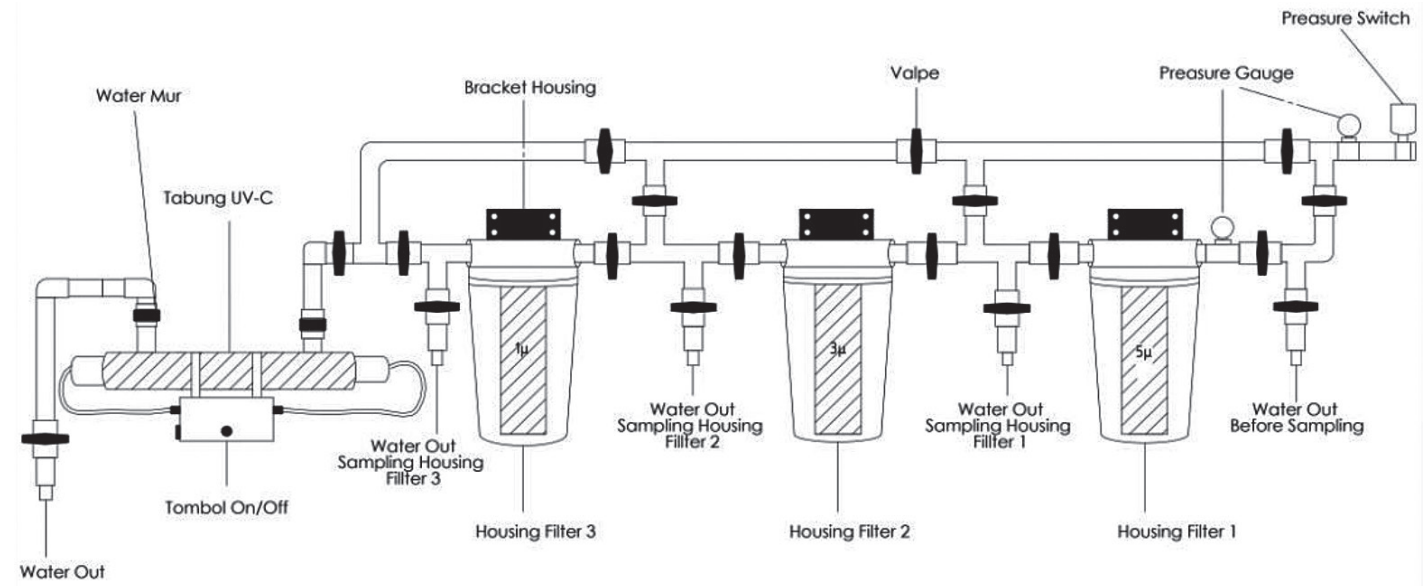

Figure 1. The 2D model of tool design

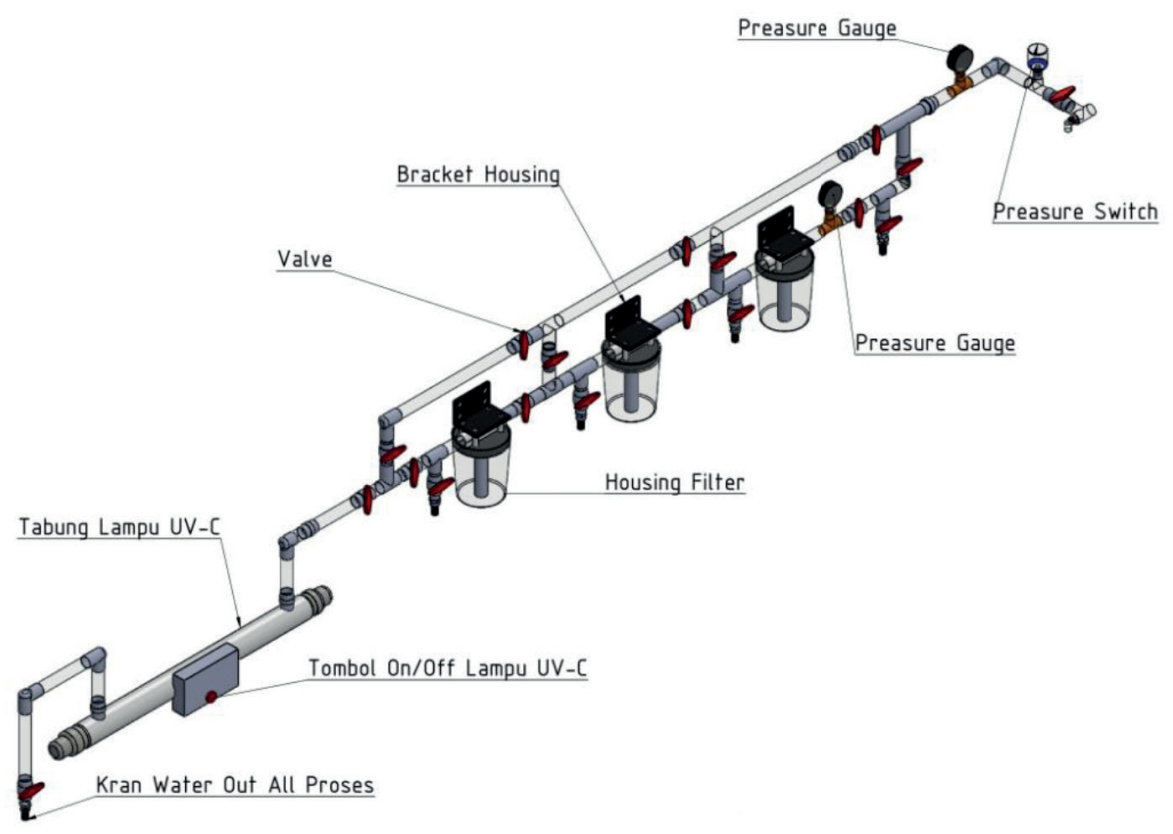

Figure 2. The 3D model of tool design

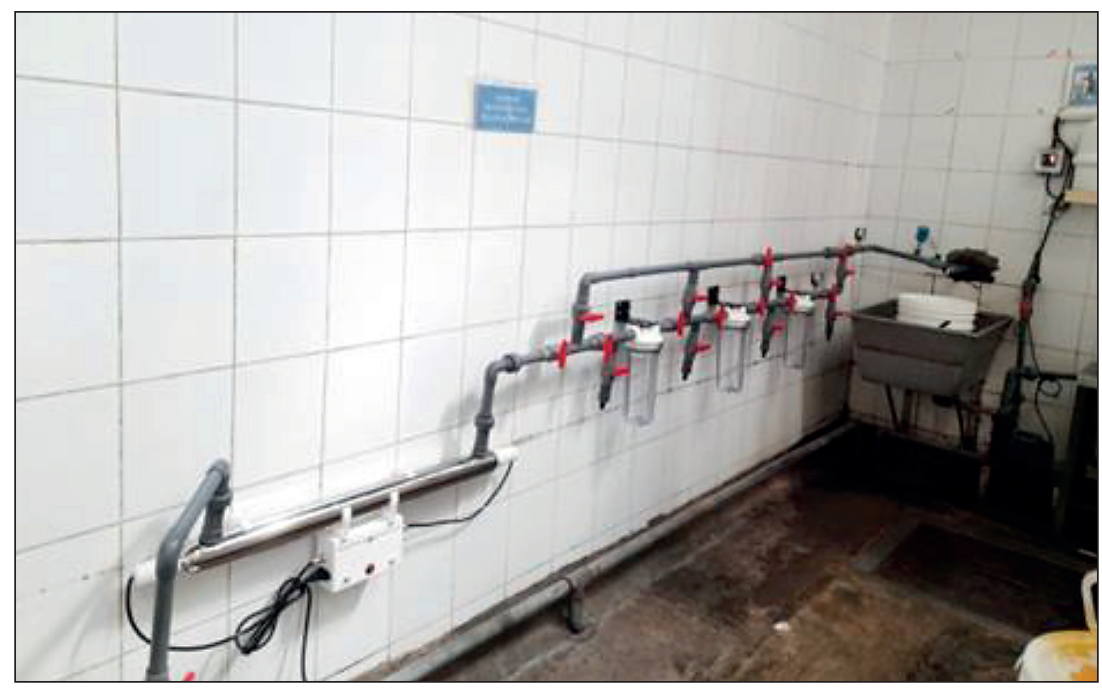

Figure 3. Melt blown filter cartridge and UV-C rays 


\section{RESULTS AND DISCUSSION}

Melt Blown filters can be easily found in the market, their sizes vary from 10 to 1 micron with an option of 10 or 20 diameters. The filter media perforated hole was very small, it ranges from 10 microns to 0.5 microns, there is a possibility that the coliform might attach to the polypropylene filter fiber layer (Kanade, 2013). The comparison between the pore size of the filter and the variation of bacteria size varies; hence, there is still a possibility for the bacteria to escape from this process (Mulyatna, 2019). Meanwhile, if there are still bacteria that pass through the Melt Blown filter, then additional UV-C Rays were added in this study. The process that enables the bacteria to be filtered by the melt blown filter was because the Klebsiella aerogenes type of Coliform has a size of 1-3 microns (Tindall et al, 2017). Generally, it has a size of $0.5 \times 0.3 \mathrm{~mm}$, it is a negative-gram bacteria without spores, moves in a clockwise rotation of peritrichous flagella, such as in Salmonella and Escherichia, and counterclockwise rotation, such as in Shigella and Klebsiella (Entjang, 2010). On the basis of the comparison between the bacteria and the filter micron, the bacteria can be filtered by the Melt Blown Filter.

Before disposing of the spent Melt Blown filters, disinfection is recommended using a minimum of $3 \%$ sodium hypochlorite solution, because that amount of concentration has an effect on reducing the Coliform and E-Coli bacteria (Umma, 2020). The purpose of disinfection is to destroy or eliminate the pathogenic organisms found on objects or tools, except for the bacterial spores, an addition of a liquid chemical mixture or wet pasteurization is required. The contact or immersion time is one of the most important factors because the effectiveness of the chemical disinfection increases within the longer duration of contact time (Rutala, 2016). The preparation starts from soaking the Melt Blown Filter with at least $3 \%$ concentration of sodium hypochlorite solution for 30 minutes; 30 minutes is the maximum time recommended by the World Health Organization (WHO) for the disinfection process using the sodium hypochlorite solution. The active ingredient of sodium hypochlorite can be found in household bleach or floor cleaners.

The wavelength of $254 \mathrm{~nm}$ UV-C rays with a power of 30 watts, was used in this experiment, which means it has used the most effective wavelength of UV Rays for drinking water treatment, which has a wavelength of $253.7 \mathrm{~nm}$ that will stop the bacteria from reproducing. Meaning that the bacteria or virus will not be harmful, because it will stop reproducing and become inactive (Sebayang et al, 2015). The maximum duration usage of UV-C is 9000 hours, which is approximately equivalent to 1 year, the maximum duration is specified because if it exceeds the service lifespan, there will be a decrease in the wavelength produced; hence, it will also decrease the UV capability in eliminating the bacteria (Schalk, 2005).

The water characteristics can directly or indirectly affect the UV rays disinfection process, the direct cause is when the characteristics of the water reduce the intensity of UV rays to reach the nucleic acids of microbes. Conversely, the indirect cause happens when the water characteristics affect the effectiveness of the rays due to the crust that is found in the lamp socket that will eventually block the UV rays; hence, it can decrease the intensity of UV rays. On the basis of on the level of water hardness, water is classified as follows: water hardness $<50 \mathrm{mg} / \mathrm{L}$ is classified as soft water, $50-150 \mathrm{mg} / \mathrm{l}$ is classified as moderately hard water, $150-300 \mathrm{mg} / 1$ is classified as hard water and $>300 \mathrm{mg} / \mathrm{l}$ is very hard water (Musiam, 2015). The maximum permissible calcium and magnesium content in drinking water is $70-200 \mathrm{mg} / \mathrm{l}$ and 30-150 mg/l (Setyaningtyas, 2008), respectively.

\section{Results of $\mathrm{pH}$, temperature and water pressure measurement}

On the basis of Table 1, the $\mathrm{pH}$ measurements result of production process water before and after being passed to the Melt Blown Filter and UV-C rays has shown that the $\mathrm{pH}$ for the 1 , 3, and 5 microns of MBF ranges from 6.93-7.11, $6.90-7.10$, and 6.92-7.11, respectively. Table 2 shows, the temperature measurements results of the production process water before and after being passed to the Melt Blown Filter and UV-C rays remain the same for every treatment, meaning that the treatment does not interfere with the production process and that the Melt Blown Filter does not affect the water temperature. The cold-water temperature is adjusted to the needs of the production process.

On the basis of Table 3, the water pressure monitoring results of production process water before being passed to the Melt Blown Filter Cartridge and UV-C rays achieved the water pressure at 0.5 bar that remained the same for 
Table 1. The $\mathrm{pH}$ measurement results of the production process water

\begin{tabular}{|c|c|c|c|c|c|c|}
\hline \multirow{2}{*}{ Repetitions } & \multicolumn{2}{|c|}{ 1 Micron of MBF and UV } & \multicolumn{2}{|c|}{ 3 Micron of MBF and UV } & \multicolumn{2}{|c|}{ 5 Micron of MBF and UV } \\
\cline { 2 - 7 } & Pre test & Post test & Pre test & Post test & Pre test & Post test \\
\hline 1 & 6.93 & 6.93 & 6.90 & 6.90 & 6.92 & 6.92 \\
\hline 2 & 7.05 & 7.05 & 7.07 & 7.07 & 7.05 & 7.05 \\
\hline 3 & 7.11 & 7.11 & 7.09 & 7.09 & 7.11 & 7.11 \\
\hline 4 & 6.96 & 6.96 & 6.99 & 6.99 & 6.95 & 6.95 \\
\hline 5 & 7.05 & 7.05 & 7.05 & 7.05 & 7.06 & 7.06 \\
\hline 6 & 7.08 & 7.08 & 7.10 & 7.10 & 7.10 & 7.10 \\
\hline
\end{tabular}

Table 2. The temperature measurements results of the production process water

\begin{tabular}{|c|c|c|c|c|c|c|}
\hline \multirow{2}{*}{ Repetitions } & \multicolumn{2}{|c|}{1 Micron of MBF and UV } & \multicolumn{2}{|c|}{3 Micron of MBF and UV } & \multicolumn{2}{c|}{5 Micron of MBF and UV } \\
\cline { 2 - 7 } & Pre test $\left({ }^{\circ} \mathrm{C}\right)$ & Post test $\left({ }^{\circ} \mathrm{C}\right)$ & Pre test $\left({ }^{\circ} \mathrm{C}\right)$ & Post test $\left({ }^{\circ} \mathrm{C}\right)$ & Pre test $\left({ }^{\circ} \mathrm{C}\right)$ & Post test $\left({ }^{\circ} \mathrm{C}\right)$ \\
\hline 1 & 8 & 8 & 8 & 8 & 8 & 8 \\
\hline 2 & 13 & 13 & 13 & 13 & 13 & 13 \\
\hline 3 & 9 & 9 & 9 & 9 & 9 & 9 \\
\hline 4 & 10 & 10 & 10 & 10 & 10 & 10 \\
\hline 5 & 8 & 8 & 8 & 8 & 8 & 8 \\
\hline 6 & 8 & 8 & 8 & 8 & 8 & 8 \\
\hline
\end{tabular}

Table 3. The water pressure monitoring results of the production process water

\begin{tabular}{|c|c|c|c|}
\hline Repetitions & $\begin{array}{c}\text { 1 Micron of } \\
\text { MBF and UV } \\
\text { (Bar) }\end{array}$ & $\begin{array}{c}\text { 3 Micron of } \\
\text { MBF and UV } \\
\text { (Bar) }\end{array}$ & $\begin{array}{c}5 \text { Micron of } \\
\text { MBF and UV } \\
\text { (Bar) }\end{array}$ \\
\hline 1 & 0.5 & 0.5 & 0.5 \\
\hline 2 & 0.5 & 0.5 & 0.5 \\
\hline 3 & 0.5 & 0.5 & 0.5 \\
\hline 4 & 0.5 & 0.5 & 0.5 \\
\hline 5 & 0.5 & 0.5 & 0.5 \\
\hline 6 & 0.5 & 0.5 & 0.5 \\
\hline
\end{tabular}

each filter. If the water pressure exceeds 1 bar (15 psi), it will cause disfunction and the filter will not work efficiently because the exceeding limit of pressure will cause the filter media to crack or tear (Ministry of Health New Zealand, 2019); hence, the monitoring of the water pressure measurement is carried out in this study that is done by checking the pressure gauge for every treatment and the results of water pressure monitoring measurements are 0.5 bar, after continuous use, there will be a decline in the effectiveness of the filter cartridge performance, which is marked by a change in color and a decrease in the water produced rate, due to the particles or microorganisms blockage in the filter; thus, the filter cartridge needs to be replaced (Indra, 2016).

\section{Total coliform test results}

Table 4 shows the total coliform of the production process water, before and after the treatment. The result of the research has shown that there is a reduction in the amount of Total Coliform in the production process water of X Industry. When a Melt Blown Filter is used without the UV-C Rays, a result of $0 \mathrm{MPN} / 100 \mathrm{ml}$ of total coliform is obtained from 1-micron filter size, with 6 repetitions. The treatment of a 1-micron size filter is used as a criterion for this experiment, meaning that the bacteria which have a size of more than 1-micron will be filtered (Yuliawati, 2011).

In the treatment of a 3-micron filter without the use of UV-C rays, it has been shown that the second and fourth repetitions do not result in the reduction of total coliform to $0 \mathrm{MPN} / 100 \mathrm{ml}$; this is possible because the 3-micron filter size is large enough for the Coliform bacteria pass. All the results of every repetition in the 5-micron filter without the use of UV-C rays have also shown that the total Coliform did not decrease to $0 \mathrm{MPN} / 100 \mathrm{ml}$ because the 5-micron filter was the largest micron size used in the experiment; hence, the bacteria could still pass the 5-micron filter, this result is in line with the research done by Yuliawati which states that the total size of Coliform is in the range of 0.5-3 microns, in addition, similar research by Tindall et al. showed that coliform with the type of Klebsiella aerogenes has a size of $1-3$ microns. 
Table 4. The pretest and posttest results of total coliform using the melt blown filter

\begin{tabular}{|c|c|c|c|c|c|c|}
\hline \multirow{2}{*}{ Repetitions } & \multicolumn{2}{|c|}{$\begin{array}{c}\text { Micron of MBF and UV } \\
\text { (MPN/100ml) }\end{array}$} & \multicolumn{2}{c|}{$\begin{array}{c}\text { Micron of MBF and UV } \\
\text { (MPN/100ml) }\end{array}$} & \multicolumn{2}{c|}{$\begin{array}{c}\text { Micron of MBF and UV } \\
\text { (MPN/100ml) }\end{array}$} \\
\cline { 2 - 7 } & Pre test & Post test & Pre test & Post test & Pre test & Post test \\
\hline 1 & 3.0 & 0.0 & 1.0 & 0.0 & 9.8 & 2.0 \\
\hline 2 & 2.0 & 0.0 & 5.2 & 1.0 & 8.6 & 1.3 \\
\hline 3 & 1.0 & 0.0 & 2.0 & 0.0 & 9.2 & 1.9 \\
\hline 4 & 5.2 & 0.0 & 7.5 & 1.0 & 7.8 & 1.4 \\
\hline 5 & 3.5 & 0.0 & 4.0 & 0.0 & 9.2 & 1.5 \\
\hline 6 & 3.0 & 0.0 & 4.0 & 0.0 & 8.7 & 1.3 \\
\hline Avg & 2.95 & 0.0 & 3.95 & 0.33 & 8.88 & 1.56 \\
\hline Min & 1.0 & 0.0 & 1.0 & 0.0 & 7.8 & 1.3 \\
\hline Max & 5.2 & 0.0 & 7.5 & 1.0 & 9.8 & 2 \\
\hline SD & 1.41 & 0.0 & 2.30 & 0.51 & 0.68 & 0.30 \\
\hline
\end{tabular}

Table 5 showed that there is a reduction in the total number of Coliforms of Production Process Water after being treated with the Melt Blown Filter and UV-C rays. The results of the total coliform in the 1,3 , and 5-microns filter were reduced up to $0 \mathrm{MPN} / 100 \mathrm{ml}$; hence, it has met the drinking water quality requirements. If unfiltered bacteria were still left following the filtration process, the next treatment of UV-C rays will eliminate the remaining bacteria by penetrating the microorganisms' cell wall and the cytoplasmic membrane. Thus, the UV rays will cause a rearrangement of the microorganisms DNA molecules that will cause the microorganisms to stop reproducing and eventually induce death (Halim, 2006). by the UV-C rays with a wavelength of $254 \mathrm{~nm}$ and a power of 30 watts. This experiment has used the most effective UV-C wavelength for the drinking water treatment, which will deactivate the bacteria and would not cause harm
(Sebayang, 2015). All of these have been proven in the results of the experiment, where all the total coliform could decrease to $0 \mathrm{MPN} / 100 \mathrm{ml}$, meaning that the result has finally met the quality standards of Drinking Water Quality based on the Minister of Health Regulation No. 492 of 2010.

\section{Water hardness test results}

Table 6 shows the total water hardness of the production process water before and after passing through the melt blown filter. The experiment showed that there is no difference in the results of the water hardness of production process water in Industry X. There are no differences in the results because the Melt Blown Filter only has the capacity for filtration nut, not adsorption. In other words, the adsorbate $\mathrm{Ca}$ (II) cannot interact with the adsorbent because the adsorbate molecule does not bind to

Table 5. The pretest and posttest results of total coliform using the melt blown filter and UV-C rays

\begin{tabular}{|c|c|c|c|c|c|c|}
\hline \multirow{2}{*}{ Repetitions } & \multicolumn{2}{|c|}{$\begin{array}{c}\text { Micron of MBF and UV } \\
\text { (MPN/100ml) }\end{array}$} & \multicolumn{2}{c|}{$\begin{array}{c}\text { Micron of MBF and UV } \\
\text { (MPN/100ml) }\end{array}$} & \multicolumn{2}{c|}{$\begin{array}{c}\text { Micron of MBF and UV } \\
\text { (MPN/100ml) }\end{array}$} \\
\cline { 2 - 7 } & Pre test & Post test & Pre test & Post test & Pre test & Post test \\
\hline 1 & 3.0 & 0.0 & 1.0 & 0.0 & 9.8 & 0.0 \\
\hline 2 & 2.0 & 0.0 & 5.2 & 0.0 & 8.6 & 0.0 \\
\hline 3 & 1.0 & 0.0 & 2.0 & 0.0 & 9.2 & 0.0 \\
\hline 4 & 5.2 & 0.0 & 7.5 & 0.0 & 7.8 & 0.0 \\
\hline 5 & 3.5 & 0.0 & 4.0 & 0.0 & 9.2 & 0.0 \\
\hline 6 & 3.0 & 0.0 & 4.0 & 0.0 & 8.7 & 0.0 \\
\hline Avg & 2.95 & 0.0 & 3.95 & 0.0 & 8.88 & 0.0 \\
\hline Min & 1.0 & 0.0 & 1.0 & 0.0 & 7.8 & 0.0 \\
\hline Max & 5.2 & 0.0 & 7.5 & 0.0 & 9.8 & 0.0 \\
\hline SD & 1.41 & 0.0 & 2.30 & 0.0 & 0.68 & 0.0 \\
\hline
\end{tabular}


Table 6. The pretest and posttest results of water hardness test using melt blown filter

\begin{tabular}{|c|c|c|c|c|c|c|}
\hline \multirow{2}{*}{ Repetitions } & \multicolumn{2}{|c|}{ 1 Micron of MBF (mg/l) } & \multicolumn{2}{|c|}{ 3 Micron of MBF (mg/l) } & \multicolumn{2}{c|}{5 Micron of MBF (mg/l) } \\
\cline { 2 - 7 } & Pre test & Post test & Pre test & Post test & Pre test & Post test \\
\hline 1 & 50.04 & 50.04 & 53.54 & 53.54 & 51.54 & 50.54 \\
\hline 2 & 49.54 & 51.01 & 51.04 & 51.54 & 51.04 & 51.54 \\
\hline 3 & 46.04 & 47.04 & 47.04 & 47.04 & 49.04 & 50.04 \\
\hline 4 & 48.04 & 47.54 & 48.04 & 47.54 & 48.04 & 49.54 \\
\hline 5 & 48.54 & 49.54 & 48.54 & 51.54 & 49.54 & 49.04 \\
\hline 6 & 49.04 & 48.04 & 48.04 & 47.54 & 46.54 & 50.54 \\
\hline Avg & 48.54 & 48.86 & 49.37 & 49.79 & 49.29 & 50.20 \\
\hline Min & 46.04 & 47.04 & 47.04 & 47.04 & 46.54 & 49.04 \\
\hline Max & 50.04 & 51.01 & 53.54 & 53.54 & 51.54 & 51.54 \\
\hline SD & 1.41 & 1.56 & 2.44 & 2.75 & 1.86 & 0.87 \\
\hline
\end{tabular}

the active site of the adsorbent (Anjani, 2014). Adsorption is a process of removing colloidal particles from organic and inorganic materials that are not deposited, several required properties are to have a large surface area, porous, active, and pure and it does not react with absorbed substances. Likewise, the use of zeolite media arrangement: the activated carbon with a height of $35 \mathrm{~cm}: 35 \mathrm{~cm}$ resulted in $94.79 \%$ of water hardness reduction efficiency for the up-flow system and $94.16 \%$ for the downflow system (Widyastuti, 2011). It can reduce the total water hardness, because activated carbon can adsorb hardness ( $\mathrm{Ca}$ and $\mathrm{Mg}$ ). Moreover, zeolites can be used as an ion exchanger due to the presence of alkaline-earth metals that could be activated as needed by heating or adding an acid or alkaline $\mathrm{pH}$. Another research also used ion exchange resins to decrease of total water hardness with a 30 minutes detention time and has resulted in a $99.4 \%$ reduction of water hardness level, from $10278.8 \mathrm{mg} / 1$. Under these conditions, anion-cation resins could be used repeatedly for a water pollutant load above $1000 \mathrm{mg} / \mathrm{l}$ (Setyabudi et al., 2020) to reduce the water hardness level, preventing the declination in the intensity of UV-C rays in reducing bacteria.

The research was conducted using the continuous method, meaning that there is no specified length of time to contact the water with a melt blown filter, the development of future research is expected to use the batch method, the determination of the contact time aims to determine how long it takes for the adsorbent to maximally absorb $\mathrm{Ca}^{2+}$ ions reached the balanced state (Irawan, 2014).

\section{The percentage reduction of total coliform}

In the use of a Melt Blown filter without the UV-C rays, the 1-micron filter resulted in $100 \%$ of the average percentage reduction of total Coliform, the average percentage reduction of total coliform in the 3-micron filter was $94.5 \%$ with a minimum reduction percentage of $80.7 \%$ and a maximum percentage reduction of $100 \%$. The average percentage reduction of total Coliform in the 5 -micron filter was $82.4 \%$, with a minimum reduction percentage of $79.3 \%$ and a maximum reduction percentage of $85.0 \%$.

The number of reduction in the Coliform bacteria in every treatment of The Melt Blown filter was obtained by calculating the differences in the total number of Coliform bacteria before and after every treatment. The average percentage reduction in the total number of Coliform bacteria using the 1,3, and 5-micron of Melt Blown filters were $100 \%, 94.5 \%$, and $82.4 \%$ of average reduction respectively. The smaller the micron size used, the higher the percentage reduction of total Coliform bacteria in the production process water (Figure 4).

The use of Melt Blown filter and UV-C rays to reduce the total Coliform of production process water at X Industry involves a Melt Blown Filter with a size of 1 micron, strengthened by the results of a decrease in total Coliform for 6 repetitions that have met the quality standards. By using a 1-micron Melt Blown Filter, Coliform bacteria with a size of $0.5-3$ microns (Yuliawati, 2011), will be filtered on the Melt Blown filter. This is in line with Mulyatna's 2019 research, who reported that the Melt Blown filter cartridges of 1 and 3 microns can eliminate Coliform in rainwater up to $100 \%$ and for the remaining 
bacteria with a size smaller than 1 micron, will be passed to the next treatment of UV-C rays that will eliminate the remaining bacteria by penetrating the microorganisms' cell wall and the cytoplasmic membrane; thus, the UV rays will cause a rearrangement of the microorganism DNA molecules stopping reproduction of microorganisms and eventually inducing death (Halim, 2006). Thus, the water used for the production process will meet the drinking water quality standards when treated using a 1-micron Melt Blown filter and UV-C rays (Figure 5).

The percentage reduction can be seen from the differences between the results before and after the filtration process. In the table above, it can be seen that the percentage of total Coliform reduction is $100 \%$ after passing through every treatment (1, 3, and 5 microns of Melt Blown Filter and UV-C rays) because $0 \mathrm{MPN} / 100 \mathrm{ml}$ of the post-test results were obtained. The use of Melt Blown filter and UV-C rays to reduce the total Coliform of production process water at $\mathrm{X}$ Industry involved a Melt Blown Filter with a size of 1 micron, strengthened by the results of a decrease in total Coliform for
6 repetitions that have met the quality standards. By using a 1-micron Melt Blown Filter, Coliform bacteria with a size of $0.5-3$ microns (Yuliawati, 2011), will be filtered on the Melt Blown filter. This is in line with Mulyatna's research that Melt Blown filter cartridges of 1 and 3 microns can eliminate Coliform in rainwater up to $100 \%$ and the remaining bacteria with a size smaller than 1 micron, will be passed to the next treatment of UV-C rays that will eliminate the bacteria by penetrating the microorganisms' cell wall and the cytoplasmic membrane; thus, the UV rays will cause a rearrangement of the microorganisms DNA molecules that will cause the microorganisms to stop reproducing and eventually induce death (Halim, 2006). Thus the water used for the production process will meet the drinking water quality standards when treated using a 1-micron Melt Blown filter and UV-C rays. There is no difference in the effectiveness of UV-C rays for the disinfection process of total coliform parameters with an average water hardness of 48-52 mg/l (soft water). The disinfection process still shows effective results, which can reduce the total coliform up to $0 \mathrm{MPN} / 100 \mathrm{ml}$.

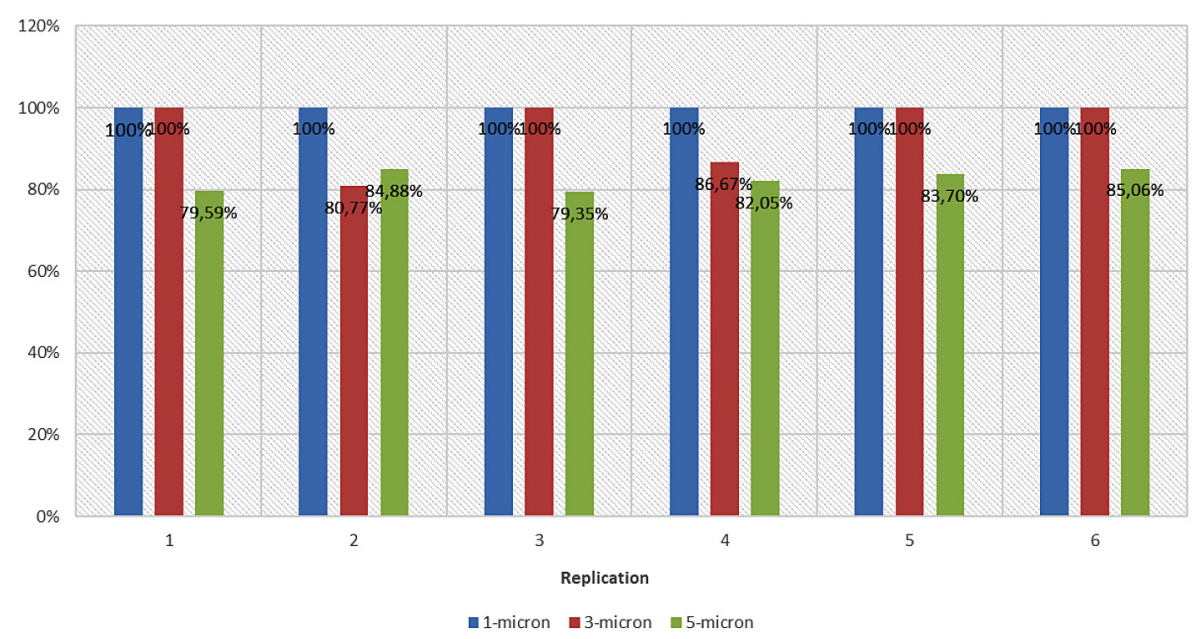

Figure 4. The percentage reduction of total coliform using the melt blown filter

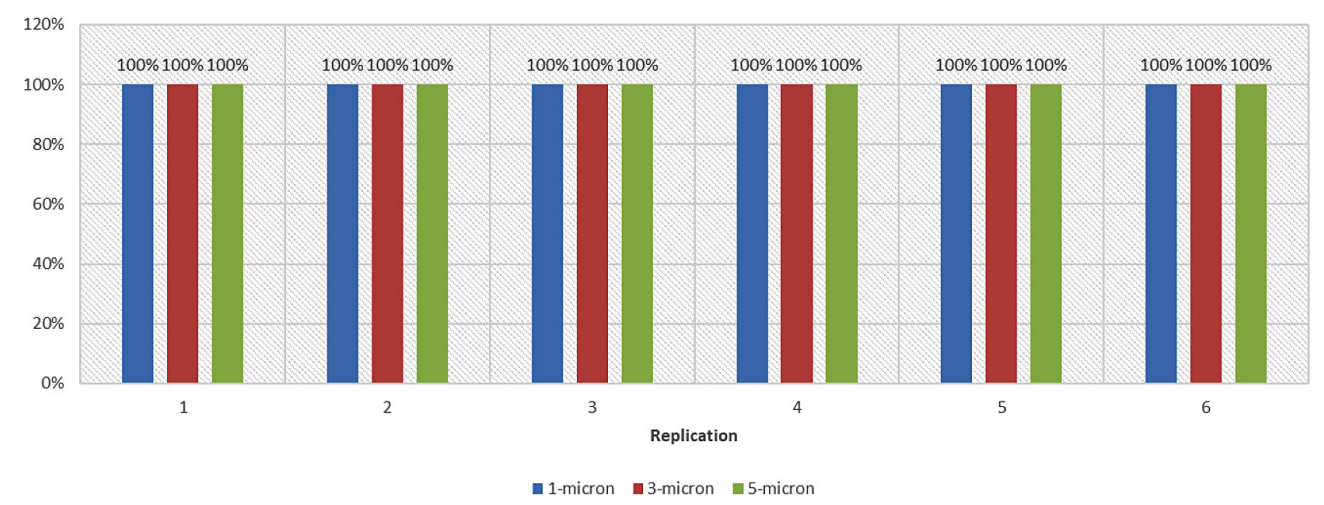

Figure 5. The percentage reduction of total coliform using the melt blown filter and UV-C rays 


\section{CONCLUSIONS}

On the basis of the results of the conducted research, the conclusions are as follows. There is a difference in the variation of Melt Blown Filter Cartridge and UV-C rays on the total Coliform reduction of the production process water, proven by the p-value $<$ alpha $(0.001<0.05)$ of One Way ANOVA test results. The average percentage reduction of total Coliform using a Melt Blown Filter Cartridge for 1, 3, and 5-micron resulted in $100 \%, 94.5 \%$, and $82.4 \%$ of average percentage reduction, respectively. The average percentage of total Coliform reduction using a Melt Blown Filter Cartridge equipped with UV-C rays is $100 \%$ for 1, 3, and 5-microns of Melt Blown Filters equipped with UV-C rays. The size of the 1-micron Melt Blown Filter Cartridge is 100\% effective in reducing the total Coliform of the production process water. The size of the 1,3 , and 5-micron Melt Blown Filter Cartridge which is equipped with UV-C rays was $100 \%$ effective in reducing the total Coliform of the production process water. There is no difference in the variation of the Melt Blown Filter Cartridge on the results of water hardness in the production process water, as proven by the results of the p-value $(0.820>0.05)$ in the Kruskal-Wallis test. Disinfection using UV rays with a total water hardness value of 48-52 $\mathrm{mg} / \mathrm{l}$ is still effective. The use of the Melt Blown Filter Cartridge could not reduce the total water hardness parameter with the continuous method.

Suggestions for industries are as follow: this tool can be used to reduce total Coliform in production process water by using a 1-micron Melt Blown Filter Cartridge and UV-C Rays; monitoring Melt Blown Filters and replacing the filter if the color has changed to green, brown, or yellow; disinfect the cartridge before disposal using the active ingredient, Sodium Hypochlorite, with a concentration of at least $3 \%$, that could be found in the content of household bleaching products and floor cleaning products; the disinfection process is by immersing the cartridge for 30 minutes; replace the UV-C lamp after one year of use, starting from July 5, 2021.

Suggestions for researchers are as follow: conducting experiment research on the saturation period of the Melt Blown Filter Cartridge; conducting experiment research for microbiological parameters of MPN of E-Coli; conducting experiment research with different inch variations of Melt Blown Filter Cartridge.

\section{REFERENCES}

1. Anjani R.P., Koestiari T. 2014. Determination of optimum mass and contact for granular carbon adsorption as $\mathrm{Pb}$ (II) heavy metal adsorbent with $\mathrm{Na}^{+}$ion competitors. UNESA Journal Chemistry, 3(3), 159-163.

2. Entjang I. 2010. Microbiology and Parasitology For Academies of Nursing and Equivalent Schools of Health Workers. PT. Citra Aditya Bakti, Bandung.

3. EPA. 2003. Ultraviolet Disinfection Guidance Manual.

4. Halim W. 2006. Disinfection of Salmonella Typhimurium in Shrimp Pond Water by Using Ozone and UV Rays. Thesis, Chemical Engineering, University of Indonesia, Depok.

5. Indra A., Agus S. 2016. Prototype of washing tool for refillable drinking water filter cartridge, 6(4), 11-18.

6. Irawan C., Atikah, Rumhayati B. 2014. Adsorption of Iron (II) by fly ash adsorbent from coal. Journal Pure App Chem Res, 3(3), 88-98.

7. Kanade P.S. 2013. Disposable filters - a review. International Journal of Innovation Research in Science, Engineering and Technology, 2(10), 5774-5779.

8. Malley James P. 2004. Inactivation of Pathogens with Innovative UV Technologies. Awwa Research Foundation.

9. Ministry of Health. 2019. Guidelines for Drinkingwater Quality Management for New Zealand Chapter 14: Treatment Processes, filtration and adsorption.

10. Mulyatna L., Astri H., Widia R.P. 2019. Elimination of total coliform in rainwater using modified zeolite filter media, activated carbon, and melt blown filter cartridge. Informatek, 21,15-26.

11. Musiam S., Darmiani S., Putra A.M.P. 2015. Quantitative analysis of total hardness of refill drinking water sold in the Kayu Tangi Area, Banjarmasin City. Manuntung Scientific Journals, 1(2), 145-148.

12. Prayitno J. 2019. Microbiological aspects of readyto-drink water treatment using reverse osmosis membranes. JRL, 12(2), 175-184.

13. Rutala W.A., Weber D.J. 2016. Disinfection and sterilization in health care facilities: An Overview and Current Issues, 30(3), 609-637.

14. Schalk S. 2005. UV-Rays for disinfection and advanced oxidation - lamp types, technologies and applications. IUVA, 8(1), 32-37.

15. Sebayang P., et al. 2015. Technology for Processing Dirty and Brackish Water into Clean and Drinking Water. LIPI Press, Jakarta.

16. Setyabudi H., et al. 2020. Removal of Sodium $(\mathrm{Na}+)$, Chloride $(\mathrm{Cl}+)$ and water hardness from brackish water with ion exchange resin. Journal of Engineering TIME, 18(1).

17. Setyaningtyas T., Andreas R., Riyani K. 2008. Potential of Humin from Soil Isolation of Baturraden 
Forest in Reducing Water Hardness. Molecule Journal, 3(2). Thesis, Departmentof Chemistry, Faculty of Mathematics and Natural Sciences, Jenderal Sudirman University, Purwokerto.

18. Tindall BJ., Sutton G.G. 2017. Enterobacter aerogenes. International Journal of Systematic and Evolutionary Microbiology, 67(2), 502-504.

19. Umma F.F. 2020. Concentration of Sodium Hypochlorite Disinfectant for Coliform and E-coli in Sumberawan Singosari River, Malang Regency. Thesis, Biology Study Program. Malang Islamic University, Malang.

20. Widyastuti S., Sari A.S. 2011. Clean Water Treatment Performance With Filtration Process In Reducing Water Hardness. Journal of Engineering TIME, 9(1).
21. Wulansarie R. 2012. Synergy of Ozone Technology and UV Rays in The Drinking Water Supply as a Breakthrough in Prevention of Diarrhea Diseases in Indonesia. Thesis, University of Indonesia, Depok.

22. Yuliana M.E. 2020. Differences in the duration of UV-C exposure to the death rate of Escherichia Coli bacteria in drinking water at PT. Sipatex Putri Lestari. Thesis, Department of Environmental Health. Bandung Health Polytechnic, Bandung.

23. Yuliawati R., Zarkowi A. 2011. Operational System and Quality of Coliform Bacteria for Refillable Drinking Water Depot at Bumi Sempaja Housing Estate, Sempaja Public Health Center Work Area in 2011. Scientific Articles. Muda Samarinda Institute of Health Science. 